\title{
Preferensi Konsumen Pada Ginger Milk Curd Dengan Penambahan Ascorbic Acid Dari Strawberry.
}

\author{
Made Citra Yuniastuti \\ Email : mac@stp-bandung.ac.id \\ Sekolah Tinggi Pariwisata Bandung
}

\begin{abstract}
Abstrak
Ginger milk curd is a kind of dessert consist of milk, sugar and ginger. The zingipan protease will curdling the milk and transform its liquid form into semi-gel. In this research some acidic acid from strawberry will be added to see if its strength the firmness of the curd. The curd was investigated using the Quantitative Descriptive Analysis regarding sensory aspects. Consumer preferences were also assessed using hedonic scale and analyse with Wilcoxon method. The results show that acidic acid from strawberry is significantly proofed strengthen the firmness of the curd and consumer prefer the flavor of the ginger milk pudding with the addition of the strawberry. The result of this research can be taken as an alternative of tourist attraction in some village which has tourism package near breeder and farmer so the visitor can utilize the raw milk and fresh strawberry into delicious dessert.
\end{abstract}

Keywords : Consumer Preference; Curd; Dessert; Ginger; Strawberry

\begin{abstract}
Abstrak
Ginger milk curd adalah sebuah dessert yang dibuat dengan cara sederhana yaitu mencampurkan susu sapi yang dihangatkan bersama gula ke dalam air perasan jahe. Enzim protease yang terdapat pada jahe akan membuat susu dari cair berubah menjadi semi padat seperti puding. Kandungan acidic acid yang terdapat pada strawberry diduga akan mampu menstabilkan dan memperkuat curd yang terbentuk. Quantitative Descriptive Analysis digunakan untuk menganalisis aspek sensori sedangkan uji hedonik dengan analisis metode wilcoxon digunakan untuk mengetahui produk manakah yang lebih disukai panelis konsumen. Hasil penelitian menunjukkan bahwa penambahan air perasan strawberry terbukti secara signifikan memperkuat curd dan hasil uji hedonik pada aspek flavor menunjukkan kesukaan panelis pada ginger milk curd dengan penambahan air perasan strawberry. Penelitian ini dapat menjadi rekomendasi bagi pelaku usaha di desa wisata untuk menambah atraksi di sekitar peternakan dan perkebunan strawberry agar pengunjung dapat langsung mengolah bahan lokal secara sederhana dan dapat langsung dikonsumsi
\end{abstract}

Kata Kunci: Consumer Preference; Curd; Dessert; Ginger; Strawberry

\section{PENDAHULUAN}

Pemanfaatan hasil peternakan dan pertanian lokal suatu daerah penting dilakukan untuk memutus rantai distribusi yang panjang dalam menyajikan sebuah makanan. Pada rangkaian penyajian tersebut, makanan penutup atau dessert memainkan peranan dalam menanamkan kesan baik yang akan diingat oleh konsumen karena penyajiannya yang biasanya diletakkan di akhir waktu makan.

Sebuah dessert sederhana dapat dibuat dengan menggunakan hasil alam yang mudah ditemui, yaitu susu sapi, jahe, gula dan strawberry. Cukup hanya dengan menggunakan empat bahan ini, sebuah produk dapat dihasilkan berupa produk makanan penutup khas yaitu ginger milk curd. Ginger milk curd adalah salah satu dessert yang berasal dari China, terbuat dari susu sapi yang dikentalkan oleh air perasan jahe sehingga teksturnya menyerupai puding yang sangat lembut dan memiliki rasa manis yang ringan dengan sedikit sensasi hangat di mulut. Keunikan dari dessert ini adalah pengental atau zat yang digunakan untuk memadatkan susu bukan agar-agar atau gelatin, melainkan berasal dari enzim protease yang terdapat pada jahe (zingibain).

Penelitian-penelitian yang dilakukan sebelumnya mengenai ginger milk curd ini 
banyak menghasilkan penemuan mengenai bahan (Hashim et al, 2011; Manzano et al, 2013) ataupun metode yang akan mempengaruhi tingkat koagulasi yang terjadi. Seperti jumlah lemak pada susu (Choi et al, 2000), perlakuan pemanasan pada susu sebelum dicampurkan dengan jahe (Choi et al, 2000), hingga penambahan ascorbic acid pada ekstrak jahe untuk lebih mempertahankan kemampuan enzim protease jahe (Su et al, 2009).

Lebih lanjut mengenai penambahan ascorbic acid dalam penelitian Su et al (2009) ini kemudian dijelaskan oleh Lersch (2014) bahwa kelemahan jahe sebagai koagulan adalah adanya enzim lain di dalam jahe yang disebut dengan PPO (polyphenol oxidase) yang menyebabkan efek browning sehingga kemampuan enzim protease jahe menjadi berkurang dan menghilang apabila disimpan dalam waktu lama. Sehingga penambahan ascorbic acid sebagai anti oksidan akan menghambat kerja enzim PPO dan enzim protease yang ada di dalam jahe masih tersisa cukup banyak untuk mampu mengkoagulasi susu.

Pada penelitian ini, penulis menggunakan hasil penelitian dalam jurnaljurnal tersebut untuk meneliti pengaruh kandungan asam dalam air perasan strawberry ke dalam air perasan jahe untuk mempertahankan fungsi enzim protease jahe. Hal ini diduga akan memperkuat sifat koagulasi atau gelling power dari jahe dan membuat koagulasi curd menjadi lebih tahan lama, karena strawberry mengandung sekitar 56mg ascorbic acid dalam setiap 100g.

Air perasan strawberry diharapkan mampu berfungsi sebagai penstabil dan memperkuat fungsi zingibain sebagai koagulan. Penelitian ini dibutuhkan untuk mengetahui profil karakteristik produk ginger milk curd yang terbuat dari susu sapi hasil perahan langsung (raw milk), serta apakah ascorbic acid yang terkandung pada strawberry lokal akan membuat kualitas tekstur hasil koagulasi enzim protease jahe menjadi lebih stabil dan kuat.
Maka, penulis akan mencoba membuat ginger milk curd dengan menggunakan raw milk (susu segar yang diperoleh langsung dari peternak) dan jahe yang digunakan pun adalah hasil pertanian masyarakat setempat. Hal ini dilakukan untuk memanfaatkan secara langsung hasil alam lokus penelitian ke dalam bidang kuliner sehingga masyarakat dapat langsung mengolah bahan yang segar langsung ke dalam produk dan dapat dijual langsung kepada konsumen tanpa harus melalui proses distribusi yang panjang.

Dessert yang dijadikan percobaan adalah ginger milk curd yang berasal dari China, dengan menggunakan susu sapi perah yang diperoleh langsung dari peternak, jahe gajah, serta strawberry hasil pertanian masyarakat setempat.

Air perasan strawberry pada produk eksperimen diharapkan mampu berfungsi sebagai ascorbic acid untuk membuat gelling properties pada ginger milk curd lebih cepat terbentuk dan juga lebih stabil dan tahan lama.

Aspek yang akan diteliti oleh penulis adalah membandingkan profil sensori dari produk eksperimen dengan produk pembanding, melakukan uji hedonik kepada konsumen, calon konsumen dan masyarakat setempat, serta sebagai informasi tambahan penulis akan menguji sampel dengan hasil penerimaan terbaik ke laboratorium uji pangan untuk mengetahui kandungan gizi di dalam produk eksperimen.

\section{METODE}

Rancangan percobaan dalam penelitian ini adalah dengan mengganti susu yang digunakan dalam pembuatan ginger milk curd serta menambahkan ascorbic acid ke dalam produk eksperimen untuk melihat apakah ada perbedaan yang terjadi pada karakteristik produk ginger milk curd. Pada tabel 1 dapat dilihat resep yang digunakan untuk membuat ginger milk curd pembanding dan eksperimen.

Ginger milk curd dibuat dengan cara memanaskan susu hingga suhu $70-80^{\circ} \mathrm{C}$ 
kemudian menuangkan susu tersebut ke dalam air perasan jahe yang sudah diporsi di dalam masing-masing cup plastik bening berukuran $100 \mathrm{ml}$. Setiap satu resep pada tabel 1 akan menghasilkan 2 cup ginger milk curd.

\section{Tabel 1}

\section{Resep Ginger Milk Curd}

\begin{tabular}{cccc}
\hline Bahan & Kontrol & $\begin{array}{c}\text { Eksperimen } \\
\text { A }\end{array}$ & $\begin{array}{c}\text { Eksperimen } \\
\text { B }\end{array}$ \\
\hline $\begin{array}{c}\text { Susu Pasteurisasi } \\
\text { (kemasan) }\end{array}$ & $200 \mathrm{ml}$ & - & \\
Raw Milk & - & $200 \mathrm{ml}$ & $200 \mathrm{ml}$ \\
Gula & $40 \mathrm{gram}$ & $40 \mathrm{gram}$ & $40 \mathrm{gram}$ \\
Air Perasan Jahe & $20 \mathrm{ml}$ & $20 \mathrm{ml}$ & $20 \mathrm{ml}$ \\
Air Perasan & - & - & $10 \mathrm{ml}$ \\
Strawberry & & & \\
(Lokal) & & & \\
\hline
\end{tabular}

Sumber: redhousespice.com (tanpa tahun), diolah

Seleksi panelis dilakukan dalam tiga tahap yaitu pengenalan, kemampuan membedakan dan uji kemampuan. Tahap akhir adalah melakukan diskusi terbuka untuk menentukan atribut sensori produk pembanding berdasarkan persepsi panelis dan disepakati bersama. Tahap ini dilakukan dengan cara memberikan produk kontrol dan panelis diminta untuk mengisi atribut sensori apa saja yang terlihat dan terasa.

Hasil diskusi penentuan atribut produk dapat dilihat pada tabel 2 dimana atribut sensori adalah aspek yang paling banyak dirasakan oleh panelis, yang kemudian diterjemahkan dalam sebuah skala dan disepakati bersama oleh para panelis. Hal ini akan memudahkan panelis dalam melakukan uji sensori untuk produk kontrol dan eksperimen.

Hasil uji sensori kemudian ditabulasi dan dianalisis dengan menggunakan bantuan aplikasi SPSS ver 25. Analisis lanjutan atau post hoc dilakukan untuk melihat aspek yang berbeda signifikan dalam kelompoknya. Pada penelitian ini penulis menggunakan post hoc Duncan test. Kemudian dilanjutkan dengan uji afektif berupa dari uji kesukaan terhadap secara keseluruhan.
Tabel 2

Aspek Sensori

\begin{tabular}{|c|c|c|c|}
\hline $\begin{array}{l}\text { Atribut } \\
\text { Sensori }\end{array}$ & Aspek & Definisi & Skala Garis \\
\hline \multirow[t]{2}{*}{$\begin{array}{l}\text { Appear } \\
\text { ance }\end{array}$} & $\begin{array}{l}\text { Kecerahan } \\
\text { Warna }\end{array}$ & $\begin{array}{l}\text { Tingkat kecerahan } \\
\text { warna putih yang } \\
\text { terlihat oleh mata di } \\
\text { bagian permukaan } \\
\text { dan sisi produk }\end{array}$ & $\begin{array}{l}\text { kiri = buram } \\
\text { kanan = cerah }\end{array}$ \\
\hline & $\begin{array}{l}\text { Tampilan } \\
\text { Permukaan }\end{array}$ & $\begin{array}{c}\text { Tekstur yang } \\
\text { tampak pada } \\
\text { permukaan dan sisi } \\
\text { produk }\end{array}$ & $\begin{array}{l}\text { kiri = pecah } \\
\text { kanan = halus }\end{array}$ \\
\hline \multirow[t]{4}{*}{$\begin{array}{l}\text { Tex } \\
\text { ture }\end{array}$} & $\begin{array}{l}\text { Tekstur } \\
\text { Firm }\end{array}$ & $\begin{array}{l}\text { Tingkat kepadatan } \\
\text { produk ketika } \\
\text { disendokkan }\end{array}$ & $\begin{array}{c}\text { kiri }=\text { tidak } \\
\text { terasa }\end{array}$ \\
\hline & & & $\begin{array}{c}\text { kanan }= \\
\text { sangat terasa }\end{array}$ \\
\hline & $\begin{array}{l}\text { Tekstur } \\
\text { Creamy }\end{array}$ & $\begin{array}{c}\text { Tingkat kelembutan } \\
\text { produk ketika } \\
\text { dimakan }\end{array}$ & $\begin{array}{c}\text { kiri }=\text { tidak } \\
\text { terasa }\end{array}$ \\
\hline & & & $\begin{array}{c}\text { kanan }= \\
\text { sangat terasa }\end{array}$ \\
\hline \multirow[t]{6}{*}{ Flavor } & Rasa Manis & $\begin{array}{c}\text { Tingkat kemanisan } \\
\text { produk }\end{array}$ & $\begin{array}{c}\text { kiri }=\text { tidak } \\
\text { terasa }\end{array}$ \\
\hline & & & $\begin{array}{c}\text { kanan }= \\
\text { sangat terasa }\end{array}$ \\
\hline & Aroma Jahe & $\begin{array}{l}\text { Tingkat rasa dan } \\
\text { aroma jahe yang } \\
\text { dirasakan ketika } \\
\text { produk dimakan }\end{array}$ & $\begin{array}{c}\text { kiri }=\text { tidak } \\
\text { terasa } \\
\text { kanan }= \\
\text { sangat terasa }\end{array}$ \\
\hline & $\begin{array}{l}\text { Hangat } \\
\text { Jahe }\end{array}$ & $\begin{array}{l}\text { Tingkat efek pedas } \\
\text { atau hangat khas } \\
\text { jahe yang dirasakan } \\
\text { ketika produk } \\
\text { dimakan }\end{array}$ & $\begin{array}{c}\text { kiri }=\text { tidak } \\
\text { terasa } \\
\text { kanan }= \\
\text { sangat terasa }\end{array}$ \\
\hline & $\begin{array}{l}\text { Aroma } \\
\text { Susu }\end{array}$ & $\begin{array}{l}\text { Tingkat rasa dan } \\
\text { aroma khas susu } \\
\text { yang dirasakan } \\
\text { ketika produk } \\
\text { dimakan }\end{array}$ & $\begin{array}{c}\text { kanan }= \\
\text { sangat terasa }\end{array}$ \\
\hline & $\begin{array}{l}\text { Aftertaste } \\
\text { Pahit }\end{array}$ & $\begin{array}{l}\text { Tingkat rasa pahit } \\
\text { yang dirasakan } \\
\text { ketika produk } \\
\text { dimakan atau rasa } \\
\text { pahit yang tertinggal } \\
\text { dan terasa setelah } \\
\text { produk dimakan }\end{array}$ & $\begin{array}{c}\text { kanan }= \\
\text { sangat terasa }\end{array}$ \\
\hline
\end{tabular}

Sumber: Olahan Penulis, 2018

Skala yang digunakan pada metode ini adalah skala angka dengan angka terkecil (1) 
untuk penilaian amat sangat tidak suka dan tertinggi (5) untuk penilaian amat sangat suka (Setyaningsih, 2010). Hasil uji kesukaan ditabulasikan kemudian dilakukan analisis dengan uji ranking Wilcoxon karena data yang dihasilkan adalah data nominal dan tidak berdistribusi normal.

\section{HASIL DAN PEMBAHASAN}

Susu sapi yang digunakan dalam penelitian ini adalah susu sapi yang diperoleh langsung dari peternak di sekitar desa Alamendah, Ciwidey, Kabupaten Bandug, Jawa Barat. Belum ada perlakuan khusus terhadap susu tersebut, sehingga dapat disebut dengan raw milk. Pada produk eksperimen, tampilan yang terlihat jelas perbedaannya adalah warnanya, yaitu yang terlihat lebih kekuningan dibandingkan dengan produk kontrol. Warna susu normal biasanya berkisar dari putih kebiruan hingga kuning keemasan. Warna putih yang terlihat dari susu merupakan akibat dari refleksi cahaya oleh globula lemak, kalsium kaseinat dan koloid fosfat. Sedangkan warna kuning susu sangat dipengaruhi oleh jenis pakan yang dikonsumsi, apabila pakan ternak tinggi kadar karotennya maka warna susu akan menjadi lebih kuning. Lemak dan beta karoten tersebut yang larut di dalam susu menciptakan warna kuning, sehingga apabila kandungan lemak dalam susu diambil, warna biru akan muncul dan warna kuning akan memudar hilang.

\section{A. Profil Sensori Produk Eksperimen}

Produk eksperimen memiliki profil sensori yang berbeda dilihat dari tiga atribut sensori pada tabel 2, kemudian hasil uji statistik disajikan pada tabel $\mathbf{3}$.

Pada aspek warna, jenis susu pada pembuatan ginger milk curd mempengaruhi kecerahan warna. Seperti diketahui bahwa kecerahan warna susu ditentukan dari banyaknya kandungan lemak yang terkandung di dalam susu. Pada susu kemasan, kandungan susu sudah distandarkan, terutama kandungan lemaknya untuk tujuan komersil.

Sebuah produsen susu kemasan dapat mengeluarkan berbagai varian susu dengan tingkat lemak yang berbeda-beda agar dapat memenuhi segmen pasar atau kebutuhan konsumen yang berbeda-beda pula, sedangkan susu yang diperoleh langsung dari peternak belum melalui perlakuan apapun. Oleh sebab itu lemak yang terkandung di dalam susu masih utuh dan akan berbedabeda tergantung dari pakan yang diberikan pada sapi, dan seiring itu pula, warna susu yang dihasilkan akan berbeda pula. Warna putih kekuningan inilah yang membuat produk eksperimen A menjadi terlihat buram dibandingkan dengan produk kontrol, karena kandungan lemak pada raw milk lebih besar dibandingkan dengan susu pasteurisasi dalam kemasan.

Tabel 3

\section{Hasil Uji Anova dan Post Hoc Duncan}

\begin{tabular}{|c|c|c|c|c|}
\hline \\
\hline $\begin{array}{c}\text { Aspek } \\
\text { Sensori }\end{array}$ & $\begin{array}{l}\text { Produk } \\
\text { Kontrol }\end{array}$ & $\begin{array}{c}\text { Eksperimen } \\
\text { A }\end{array}$ & $\begin{array}{c}\text { Eksperimen } \\
\text { B }\end{array}$ & Sig \\
\hline $\begin{array}{l}\text { Keceraha } \\
\text { n Warna }\end{array}$ & $11,55(1,45) \mathrm{c}$ & $7,58(1,67) b$ & $3,22(2,13) \mathrm{a}$ & 0,000 \\
\hline Tampilan & & & & \\
\hline $\begin{array}{l}\text { Permuka } \\
\text { an/sisi }\end{array}$ & $9,14(4,61) b$ & $6,32(2,59) \mathrm{ab}$ & $5,29(4,08) \mathrm{a}$ & 0,088 \\
\hline $\begin{array}{l}\text { Tekstur } \\
\text { Creamy }\end{array}$ & $6,67(3,74) \mathrm{a}$ & $6,69(1,92) \mathrm{a}$ & $7,06(2,96) \mathrm{a}$ & 0,947 \\
\hline $\begin{array}{l}\text { Tekstur } \\
\text { Firm }\end{array}$ & $4,13(2,69) \mathrm{a}$ & $7,01(2,06) b$ & $9,27(3,62) b$ & 0,002 \\
\hline $\begin{array}{l}\text { Rasa } \\
\text { Manis }\end{array}$ & $6,50(2,97) \mathrm{a}$ & $7,97(3,31) \mathrm{a}$ & $9,21(3,02) \mathrm{a}$ & 0,168 \\
\hline $\begin{array}{l}\text { Aroma } \\
\text { Jahe }\end{array}$ & $9,54(2,90) b$ & $7,30(2,94) \mathrm{ab}$ & $5,04(2,60) \mathrm{a}$ & 0,005 \\
\hline $\begin{array}{l}\text { Pedas } \\
\text { Jahe }\end{array}$ & $8,98(2,64) b$ & $6,63(2,26) a b$ & $5,34(2,86) \mathrm{a}$ & 0,014 \\
\hline $\begin{array}{c}\text { Aroma } \\
\text { Susu }\end{array}$ & $5,20(3,04) \mathrm{a}$ & $7,25(3,12) \mathrm{a}$ & $6,81(3,19) \mathrm{a}$ & 0,318 \\
\hline $\begin{array}{l}\text { Aftertast } \\
\mathrm{e}\end{array}$ & $7,59(3,84) \mathrm{a}$ & $5,58(2,78) \mathrm{a}$ & $5,09(3,20) \mathrm{a}$ & 0,220 \\
\hline
\end{tabular}

Sumber: Olahan Penulis, 2018

Perbedaan kandungan protein dan lemak pada susu mempengaruhi tekstur creamy dan tekstur firm pada produk. Seperti pada penelitian yang telah dilakukan oleh Choi et al (2000) bahwa kandungan lemak yang tinggi pada susu akan membuat curd lebih kuat. Susu yang digunakan pada eksperimen 
A memiliki protein yang lebih rendah namun memiliki kandungan lemak yang lebih tinggi. Sehingga koagulasi protein yang terjadi tidak sebanyak koagulasi yang terjadi pada produk kontrol, ada sebagian kecil whey yang cepat terpisah. Meskipun begitu, curd yang terbentuk ternyata lebih kokoh dibandingkan dengan dengan produk kontrol. Perlu dipertimbangkan pengurangan penggunaan jumlah air perasan jahe ketika membuat ginger milk curd dengan menggunakan raw milk, karena curd lebih mudah terbentuk.

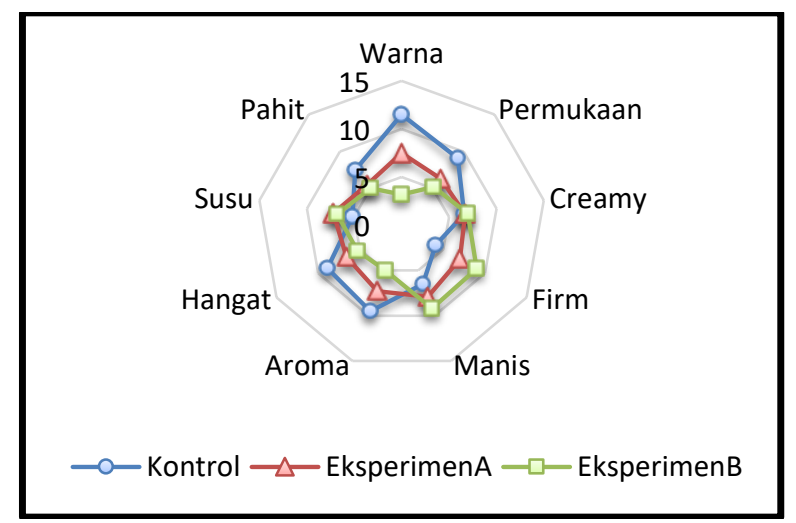

Sumber: Hasil Olahan Penulis, 2018

\section{Gambar 1 Radar Chart Produk Kontrol, Eksperimen A, Eksperimen B}

Produk ginger milk curd memiliki flavor yang kompleks, sehingga banyak aspek yang dapat dinilai selain rasa manis. Selanjutnya adalah aroma jahe serta rasa pedas jahe yang ternyata memiliki perbedaan yang signifikan dimana produk eksperimen A dinilai memiliki aroma serta rasa jahe yang lebih ringan dibandingkan dengan produk kontrol. Secara berturut-turut, nilai rata-rata aspek sensori aroma jahe dan rasa pedas jahe untuk produk kontrol adalah 9,54 dan 8,98 sedangkan untuk produk eksperimen A adalah 7,30 dan 6,63. Penurunan nilai sensori ini berkaitan dengan rasa manis yang berbeda dan juga tekstur creamy yang dirasakan. Kedua poin ini meningkat untuk produk eksperimen A, sehingga akan menutupi aroma jahe dan rasa pedas jahe karena panelis menilai rasa manis yang lebih mendominasi dibandingkan dengan rasa pedasnya.
Produk ginger milk curd eksperimen B adalah ginger milk curd yang terbuat dari raw milk serta ditambahkan air perasan strawberry. Penambahan air perasan strawberry ini diharapkan akan membuat curd pada produk menjadi lebih kokoh. Dari hasil pra eksperimen, diketahui bahwa air perasan strawberry tidak dapat terlalu banyak ditambahkan ke dalam ginger milk curd karena akan membuat curd menjadi terpisah dengan whey. Susu mengandung protein yang disebut dengan kasein yang tersebar dengan merata didalam susu, dengan bantuan muatan negatif yang menjaga kasein ini tersebar dengan merata. Saat susu menjadi asam, muatan negatif tersebut menjadi netral sehingga protein kasein menjadi terkumpul dan menyebabkan susu menjadi berbutir dan mengental. Semakin banyak asam yang ditambahkan maka semakin banyak gumpalan yang dihasilkan.

Pada umumnya, mencampur susu dengan bahan makanan lain adalah salah satu cara untuk menambah variasi rasa, dan sebagai alternatif bagi orang yang tidak menyukai aroma susu. Susu dan buah-buahan sudah sering digunakan dalam pembuatan berbagai makanan dan minuman. Akan tetapi, pada kondisi atau orang tertentu yang alergi dengan laktosa atau penderita maagh, maka akan menimbulkan gangguan pencernaan. Jadi, mencampurkan susu dengan bahan lain bukan suatu hal yang membahayakan kesehatan yang bermakna secara umum, namun hanya bagi orang-orang tertentu saja.

Pada produk eksperimen B, gumpalan yang terjadi pada susu akibat dari enzim zingipan dan acid tidak cukup kuat untuk membuat curd terpisah dari whey nya, namun sudah cukup untuk membuat protein terkoagulasi. Produk ini masih layak untuk disajikan sebagai ginger milk curd, karena bagian permukaan produk tidak terpisah dan produk masih mampu menahan beban selama beberapa saat.

Pada aspek appearance, produk eksperimen B memiliki warna yang berbeda signifikan dengan produk kontrol. Hal ini disebabkan warna susu yang memang sudah 
berbeda (lebih suram) serta warna air perasan strawberry yang berwarna merah kecoklatan. Selain itu, produk berwarna lebih suram karena whey yang mulai terpisah dari curd. Whey ini tercampur dengan air perasan jahe dan air perasan strawberry sehingga terlihat berwarna hijau kecoklatan.

Selanjutnya, tekstur firm terbukti berbeda signifikan dengan produk kontrol. Hal ini membuktikan hasil penelitian sebelumnya yang dilakukan oleh $\mathrm{Su}$ et al (2009) dan Lersch (2014) bahwa kandungan ascorbic acid dalam strawberry membuat hasil koagulasi jahe menjadi lebih kuat. Meskipun kekokohan curd ini pada sisi lain membuat whey sedikit terpisah. Pada wadah yang terlihat tidak terpisah curd-nya, penulis dapat mengamati bahwa produk eksperimen B masih dapat diuji kekokohan curdnya dengan meletakkan sendok diatas permukaan produk. Lamanya produk dapat menahan sendok akan membantu merekomendasi hiasan seberat apa yang dapat diletakkan diatas curd. Untuk produk eksperimen $\mathrm{B}$, tidak mungkin meletakkan hiasan berupa potongan buah, karena bobotnya yang berat. Dekorasi coklat sederhana atau daun mint lebih cocok digunakan untuk produk eksperimen B.

Pada aspek selanjutnya yaitu aroma jahe dan pedas jahe, produk eksperimen B berbeda signifikan dengan produk kontrol. Perbedaan ini dipengaruhi oleh aroma strawberry yang kuat sehingga dapat menutupi aroma jahe serta rasa yang lebih manis sehingga mengimbangi rasa pedas jahe yang tajam. Sedangkan pada aspek aroma susu, produk eksperimen B tidak berbeda signifikan dengan produk kontrol. Produk eksperimen B berada pada subset yang sama dengan produk kontrol dan eksperimen A.

Aspek terakhir yang dilihat dari flavor adalah aftertaste pahit, yang ternyata memiliki nilai lebih rendah dibandingkan dengan produk kontrol, meskipun secara statistik tidak berbeda signifikan. Aftertaste pahit pada jahe merupakan aspek sensori yang sangat subjektif dan berhubungan dengan kesukaan seseorang. Kadar pahit yang sama akan dinilai berbeda oleh orang yang kesukaannya terhadap rasa jahe berbeda pula. Penambahan strawberry dapat mengurangi aftertaste tersebut meskipun tidak signifikan.

\section{B. Preferensi Konsumen}

Uji preferensi dilakukan untuk mengetahui respon panelis konsumen terhadap produk eksperimen. Sebanyak 60 orang pengunjung tempat wisata di Ciwidey, Kabupaten Bandung diminta untuk mencoba kedua produk eksperimen kemudian mengisi respon kesukaannya terhadap ketiga atribut sensori produk. Skala yang digunakan adalah 1 untuk sangat tidak suka hingga 5 untuk sangat suka.

Panelis konsumen yang berpartisipasi terdiri dari $75 \%$ wanita. Kelompok usia terbanyak yang menjadi panelis yaitu $50 \%$ dibawah usia 25 tahun dan dari semua panelis, sebanyak $66,67 \%$ menyukai bandrek serta $43,37 \%$ sering berkunjung ke ciwidey. Setelah mentabulasi hasil uji kesukaan panelis konsumen, penelitian dilanjutkan dengan menguji hasil kuesioner yang diisi oleh panelis.

Hasil uji statistik dengan menggunakan metode Wilcoxon menunjukkan bahwa ada perbedaan kesukaan antara masing-masing aspek sensori, baik secara positif maupun negatif. Pada tabel 4 dapat dilihat hasil perhitungan statistik terhadap kesukaan panelis konsumen dengan menggunakan metode Wilcoxon

\begin{tabular}{ccrcc}
\multicolumn{5}{c}{ Tabel 4} \\
Hasil Uji Hedonik $(\mathbf{N}=\mathbf{6 0})$ \\
\hline \multicolumn{4}{c}{ Mean } \\
Aspek Sensori & $\mathrm{N}$ & Rank & Sig \\
\hline Appearance & Negative Ranks & 39 & 25,50 & 0.019 \\
& Positive Ranks & 15 & 32,70 & \\
Texture & Ties & 6 & & \\
& Negative Ranks & 38 & 25,03 & 0.027 \\
& Positive Ranks & 15 & 32,00 & \\
Flavour & Ties & 7 & & \\
& Negative Ranks & 19 & 27,72 & 0.040 \\
& Positive Ranks & 35 & 30,31 & \\
& Ties & 6 & & \\
\hline
\end{tabular}

Sumber: Olahan Penulis, 2018

Hasil uji statistik yang dapat dilihat di tabel 4, untuk aspek appearance, 39 orang 
menyatakan lebih menyukai produk eksperimen A dibandingkan dengan produk eksperimen $\mathrm{B}$ dan 15 orang lainnya menyatakan lebih menyukai produk eksperimen B dibandingkan dengan produk eksperimen A sementara 6 orang lainnya menyatakan sama-sama menyukai produk eksperimen A dan produk eksperimen B. Perbedaan ini signifikan karena nilai sig pada tabel lebih kecil dari 0,05. Dapat dikatakan bahwa ada perbedaan kesukaan yang siginifikan antara produk eksperimen A dan produk eksperimen B dimana panelis lebih menyukai produk eksperimen A dibandingkan dengan produk eksperimen $\mathrm{B}$.

Penampilan atau appearance produk ginger milk curd eksperimen A memang terlihat lebih mulus dan lebih cerah dibandingkan dengan ginger milk curd eksperimen B. panelis awam akan lebih menyukai produk yang terlihat lebih cerah dan mulus karena persepsi untuk ginger milk curd tersebut yang menyerupai puding, sedangkan produk eksperimen B yang terlihat lebih suram akan membuat persepsi konsumen terhadap produk tersebut menjadi menurun.

Kesulitan yang dialami penulis dalam membuat produk ginger milk curd adalah menjaga wadah tidak terlalu banyak bergoyang apalagi terbentur. Untuk pembuatan produk dalam jumlah yang banyak diperlukan kehati-hatian agar wadah dapat berpidah tempat dengan benturan yang minim. Apabila wadah terlalu banyak digoyangkan maka curd tidak akan terbentuk. Begiitu pula apabila produk yang sudah jadi dan siap saji kemudian terguncang, maka curd akan dengan mudah terpisah dari wheynya. Hal ini membuat produk ginger milk curd kurang cocok apabila dijadikan souvenir khas daerah yang dapat dibawa pulang oleh pengunjung. Produk ini akan lebih sesuai untuk hidangan yang langsung dimakan di tempat dengan hiasan sederhana dan ringan. Selain itu, produk ginger milk curd lebih menarik apabila disajikan di dalam mangkuk porcelain atau kaca yang sederhana dan elegan.
Pada aspek tekstur, dapat dilihat kembali tabel 4 terjadi penurunan kesukaan sebanyak 38 orang, peningkatan kesukaan sebanyak 15 orang dan seri sebanyak 7 orang. Ini dapat diartikan bahwa sebanyak 38 orang lebih menyukai tekstur produk eksperimen A dibandigkan dengan tekstur produk eksperimen B, 15 orang menyatakan lebih menyukai tekstur produk eksperimen B dibandingkan tekstur produk eksperimen A dan 7 orang menyatakan sama kesukaannya terhadap tekstur produk eksperimen A dan produk eksperimen B. Secara statistik, perbedaan kesukaan terhadap tekstur ini signifikan, dimana tekstur produk A lebih disukai dibandingkan dengan tekstur produk eksperimen B.

Seperti yang sudah dibahas pada uji sensori, bahwa tekstur produk eksperimen B jika dibandingkan dengan produk eksperimen A terasa lebih firm, dan perbedaan tekstur ini signifikan. Melihat pola kesukaan konsumen yang ternyata lebih menyukai produk eksperimen A maka dapat dikatakan tekstur yang lebih disukai oleh konsumen adalah yang lebih lembut dan creamy. Curd yang terpisah memang menjadi lebih firm dan terkadang kualitas sensori ketika memakan curd yang telah terpisah dari whey menjadi menurun.

Aspek terakhir adalah flavor atau rasa dan aroma secara keseluruhan ketika memakan produk ginger milk curd eksperimen. Perbedaan kesukaan pada aspek ini signifikan karena nilai sig lebih kecil daripada 0,05. Panelis konsumen yang menyatakan lebih menyukai flavor produk eksperimen A adalah 19 orang dan yang lebih menyukai flavor produk eksperimen B adalah 35 orang sedangkan 6 orang lainnya menyatakan sama-sama menyukai kedua produk. Hasil ini menunjukkan bahwa panelis lebih condong menyukai flavor dari produk eksperimen B. berkaitan dengan kesukaan panelis terhadap bandrek, aspek rasa ini juga dipengaruhi kesukaan panelis terhadap bandrek. Pada orang-orang tertentu, rasa manis dari strawberry akan menutupi rasa dan aroma jahe yang kuat sedangkan sebagian 
lainnya menjadi suka dengan rasa produk karena rasa dan aroma jahe yang timbul tidak terlalu kuat akibat dari penambahan strawberry.

Hasil ini menunjukkan bahwa peluang penambahan air perasan strawberry lebih diperlukan untuk menambah variasi rasa, selain juga untuk memperkokoh curd dari produk. Meskipun hasil uji statistik penambahan air perasan strawberry terbukti secara signifikan membuat produk menjadi lebih firm, ternyata konsumen kurang menyukai tekstur tersebut.

\section{KESIMPULAN}

Raw milk atau susu segar yang baru diperah dapat langsung dimanfaatkan untuk dibuat menjadi ginger milk curd dan penambahan air perasan strawberry dapat menambah kekokohan tekstur curd pada produk. Penggunaan susu yang berbeda akan mempengaruhi warna dan tekstur firm dari ginger milk curd yang dibuat. Perbedaan ini juga dipengaruhi oleh kandungan yang berbeda yang terdapat di dalam susu, dimana kandungan tersebut juga turut mempengaruhi rasa dan aroma. Raw milk dapat digunakan untuk membuat ginger milk curd tanpa terlalu banyak mengubah karakteristik sensori produk itu sendiri.

Pada beberapa perbedaan yang terlihat berbeda signifikan, nilai rata-ratanya menunjukkan penurunan pada aspek warna, aroma jahe dan pedas jahe sedangkan peningkatan nilai sensori rata-rata ada pada aspek tekstur. Hal ini membuktikan dugaan penulis dan memperkuat penelitian sebelumnya bahwa kandungan acid dalam jumlah tertentu dapat meningkatkan kerja enzim protease pada jahe serta membantu pembentukan curd itu sendiri.

Penambahan air perasan strawberry dapat menambah kekokohan curd, namun panelis konsumen lebih menyukai tekstur produk eksperimen yang dibuat tanpa penambahan air perasan strawberry. Maka penambahan air perasan strawberry dapat dilakukan sebatas untuk menambah pilihan rasa saja, karena strawberry dapat menutupi aroma dan pedas jahe yang menyengat dengan rasa dan aroma manis yang berasal dari strawberry.

Ginger milk curd masih kurang populer di Indonesia. Produk ini bisa menjadi alternatif atraksi yang dapat diselenggarakan oleh pengelola desa wisata yang terintegrasi dengan peternak sapi dan perkebunan strawberry. Penelitian lanjutan diperlukan untuk lebih fokus dalam pengembangan produk ini. Diperlukan tanggapan beberapa pihak seperti peternak, petani, masyarakat sekitar serta stakeholder lainnya yang terkait. Selain itu, tanggapan para calon konsumen juga diperlukan mengenai proses pembuatannya. Hal ini dapat dilakukan baik dengan cara penelitian lanjutan ataupun dalam bentuk pengabdian kepada masyarakat.

Mengingat tekstur ginger milk curd yang rapuh maka tidak memungkinkan produk ini dijadikan produk dalam kemasan untuk oleholeh yang dapat dibawa pulang oleh turis. Produk ini akan lebih sesuai apabila dijual di restoran atau hotel setempat sebagai kuliner khas yang dapat berupa makanan penutup atau sajian selamat datang. Pembuatan yang relatif mudah dan singkat ini dapat diaplikasikan baik untuk tingkat UKM maupun hotel berbintang.

Panelis konsumen lebih menyukai tekstur lembut dengan aroma jahe yang tidak terlalu menyengat. Air perasan jahe dapat dikurangi hingga $7 \mathrm{ml}$ per $100 \mathrm{ml}$ susu. Namun tingkat pembentukan curd dengan perbandingan ini sangat rapuh jika menggunakan susu pasteurisasi dalam kemasan. Penggunaan strawberry mendapat respon yang cukup baik dari pengunjung selain juga dapat memperkokoh tekstur curd, untuk mendapatkan variasi rasa lainnya diperlukan penelitian lanjutan dengan menggunakan buah asam atau buah non asam lainnya. Namun perlu dipertimbangkan kesesuaiannya dengan aroma dan rasa jahe. 


\section{DAFTAR PUSTAKA}

Budiman, S dan Saraswati, D. (2007). Berkebun Stroberi Secara Komersial. Jakarta: Penebar Swadaya.

Choi, K.H., Laursen, R.A. (2000). Amino Acids sequence and Glycan Structures of Cysteine Proteases with Proline Specificity from Ginger Rhizome Zingiber Officinale. European Journal Biochem 267 (5): 1516-1526

Figoni, P. (2011). How Baking Works: Exploring the Fundamentals of Baking Science. New York: John Wiley \& Sons.

Hashim, M.M., Mingsheng, D., Iqbal, M.F., Xiaohong, C. (2011). Ginger Rhizome as a Potential Source of Milk Coagulating Cysteine Protease. Phytochemistry (72): 458-464

Labensky, SR., Martel, P \& Van Damme, E. (2016). On Baking: A Textbook of Baking and Pastry Fundamentals $3^{\text {rd }}$ $e d$. New Jersey: Pearson Education Inc.

Mazorra-Manzano, M.A., Perea-Gutierrez, T.C., Lugo-Sanchez, M.E., RamirezSuarez, J.C., Torres-Lianez, M.J., Gonzalez-Cordova, A.F., VallejoCordoba, B. (2013). Comparison of the Milk Clotting Properties of Three Plant Extracts. Food Chemistry (141): 19021907.

Nafi, A., Foo, H.L., Bakar, J., Ghazali, M \& Hasanah. (2013). Properties of proteolytic enzyme from ginger (Zingiber officinale Roscoe). International Food Research Journal, 20, 363-368.

Nurmalina, R \& Valley, B. (2012). 24 Herbal Legendaris Untuk Kesehatan Anda. Jakarta: PT. Elex Media Komputindo.
Resnawati, H. (Tanpa tahun). Kualitas Susu Pada Berbagai Pengolahan dan Penyimpanan. Semiloka Nasional Prospek Industri Sapi Perah Menuju Perdagangan Bebas 2020. Pusat Penelitian dan Pengembangan Peternakan Kementerian Pertanian: 497-502

Rinsky, G \& Rinsky, L.H. (2009). Pastry Chef Companion. Hoboken: John Wiley \& Sons.

Rukmana, R. (2000). Usaha Tani Jahe. Yogyakarta: Kanisius.

Setyaningsih, D., Apriyantono, A \& Sari, M.P. (2010). Analisis Sensori untuk Industri Pangan dan Agro. Bogor: Penerbit IPB Press.

Setyawan, AD. (2002). Keragaman Varietas Jahe (Zingiber officinale Rosc.) berdasarkan Kandungan Kimia Minyak Atsiri. BioSmart 4 (2): 48-54. Jurusan Biologi FMIPA UNS. Surakarta

Su, HP., Huang, M.J. \& Wang, H.T. (2009). Characterization of Ginger Proteases and Their Potential as a Rennin Replacement. Journal of Food and Agriculture May 2009. 89 (7): 11781185. Wiley Online Library.

Lersch, M. (2014). Ginger Milk Curd. https://blog.khymos.org/2014/02/24/gi nger-milk-curd/ 